\title{
Offshore Outsourcing of Manufacturing SMEs and Developing Value Ladder
}

\author{
Muhammad Mohiuddin*, Samim-Al Azad \\ *Thompson Rivers University
}

\begin{abstract}
Research on production efficiency from offshore outsourcing is abundant. In a hyper-competitive business environment, the SMEs need not only efficiency related strategy but also growth oriented strategy by improving their dynamic capabilities that lead towards Sustainable Competitive advantages (SCA). However, there are insignificant research that addresses the offshore outsourcing as a medium of dynamic capabilities development. The objective of this paper is to explore on how manufacturing SMEs enhance their dynamic capabilities through offshore outsourcing in addition to the efficient related advantages that firms gain from this strategy. Organizational dynamic capabilities development process includes among others increasing focus on Core competency of the focal firm, developing innovation capabilities, increasing market share in existing and/or new markets, and improving flexibility of the firm to match with the volatile market trends. Results from the case study on ten manufacturing SMEs from Quebec show that offshore outsourcing contributes to the development of dynamic capabilities with varying degrees of success. It shows an evolutionary path of dynamic capability development process. This article open-up a new horizon on offshore outsourcing research and shed light on growth perspective and sustainable competitive advantages (SCA) that offshore outsourcing bring to manufacturing SMEs despite the size and resource constraints that they inherit.
\end{abstract}

Key words: Dynamic capability, Offshore outsourcing, SMEs.

\section{INTRODUCTION}

In the global value chain (GVC) era, manufacturing SMEs distribute their "tasks" across the planet depending on the service that offshore suppliers can offer competitively (Jensen, \& Pedersen, 2011). The previous research on offshore outsourcing was dominated by the cost advantages of arm's-length offshoring of large enterprises (LE). Offshore outsourcing, however, can also enable SMEs to have access to emergent expertise and low-cost/high-value innovations (Rashid \& Al-Azad, 2013) and develop dynamic capabilities for sustainable competitive advantage (SCA). According to Helfat, Finkelstein, Mitchell, Peteraf, Singh, Teece, and Winter (2007), dynamic capability is the capacity of an organization to purposefully extend, create, or modify its resource base. It is a specific organizational and strategic processes of configuring resource base of firms (Eisenhardt \& Martin, 2000). The continuous renewable nature of these capabilities can enable firms to adapt with rapidly changing market conditions and be competitive in the marketplace. The SMEs, in general, lack internal capabilities compared to large companies and can benefit from offshore supplier's resources and capabilities and 
$8^{\text {th }}$ International Conference on Modern Research in

Management, Economics and Accounting

October 19-21, 2018 / Munich - Germany

minimize consequences of their internal shortcomings. They can overcome size-induced resource constraints and develop networked structure and can behave in the marketplace as a single larger firm, thereby achieving market penetration through synchronized competency building (Liesch, Buckley, Simonin, \& Knight, 2012). Organizational capability, business process, market development, and product innovation are critical for manufacturers to compete in the GVC. Rapid changes in the organizational environment force firms to integrate, build, and reconfigure their resources, competences, and capabilities in a way that can regenerate dynamic capabilities continuously and follow the rhythms of the changing business environment. Dynamic capabilities thus are the organizational and strategic routines by which firms achieve new resource configurations as markets emerge, collide, split, evolve, and die (Eisenhardt \& Martin, 2000; Mohiuddin \& Su, 2013). In a highly competitive market, SMEs need to redesign their value chain along with organizational and network capability in order to remain competitive in the marketplace. To the best of our knowledge, there is insignificant empirical research that addressed the role of offshoring in reconfiguring and re-designing firm activities with inter-firm resources and capabilities for developing organizational dynamic capabilities of manufacturing SMEs. The current research sheds light on exploring how offshoring contributes to developing organizational dynamic capabilities of manufacturing SMEs by focusing more on their core competencies (CC), developing innovation capabilities, accelerating new product development process, and enhancing organizational flexibility in collaboration with suppliers.

This paper has multiple objectives. First of all, this paper sheds light on leveraging resources and competences of supplier firms through offshore outsourcing. Whereas the dominant view on offshore outsourcing is to reduce production cost, this paper rather looks to organizational capability development process through building, integrating, and reconfiguring inter-firm resources and competences of offshoring SMEs with those of their suppliers that lead towards SCAs. Section 2 grounds the research topic into the wider research field as well as highlighting the research gaps. Section 3 describes the methodology of this study and Section 4 offers the results and analysis and concurrently demonstrates the theory development process. Finally, Section 5 adds the conclusion.

\section{LITERATURE REVIEW}

\subsection{Research Context of offshore outsourcing}

Offshore outsourcing is a multidimensional and multifaceted business strategy explained by theoretical perspectives brought from economics, strategy, system science, and sociology. Treffler (2008) asserts that many firms have yet to recognize the sea change in their sourcing possibilities. Nor do they adequately understand that offshoring can enable them to concentrate on core activities that improve their efficiency and competitiveness and enhance productivity and performance (Gulbrandsen, Sandvik, \& Haughland, 2009; Javalgi, Dixit, \& Scherer, 2009; Mohiuddin \& Su, 2013; Musteen, 2016). By focusing on the CC, firms can improve organizational skills, specialization, invest more resources to enable them to adapt quickly to the changing environment, overcome challenges, and finally prosper in the long run. Offshoring tasks to other locations enjoying a comparative advantage could increase productivity in the tasks retained by the outsourcing firm. Jones (2008) and Bhagwati, Panagariya, and Srinivasan 
$8^{\text {th }}$ International Conference on Modern Research in

Management, Economics and Accounting

October 19-21, 2018 / Munich - Germany

(2004) argue that offshore outsourcing is fundamentally a trade phenomenon, and results in gains from international trade. Moreover, offshore outsourcing of manufacturing SMEs is different from those of MNCs. Scully and Fawcett (1994) state that SMEs get few benefits from offshoring and viewed it as less helpful in competing with low-cost manufacturers. On the other hand, Sinha, Akoorie, Ding, and Wu (2011) find that manufacturing offshore outsourcing enables SMEs to gain the benefits of flexibility, lower production costs, and customized delivery without incurring additional costs. Manufacturing offshore outsourcing enables SMEs to operate within the constraints of its limited physical and managerial resources. Among the multiple theories, two influential theories in the study of offshore outsourcing have been TCE and the RBV (Jiang, Belohlav, \& Young, 2007; Vivek, Banwet, \& Shankar, 2008). These theories assist to explain the motivation of SMEs offshoring, such as reduced cost and greater efficiencies, concentration on $\mathrm{CC}$, overcoming resource constraints and size disadvantages by tapping into resources owned by others, and gaining flexibility, network and learning benefits (Gregorio, Musteen, \& Thomas, 2009). However, these theories do not explain how offshoring SMEs can reconfigure their resources to develop organizational capability to gain SCA. Dynamic capabilities view (DCV) fills this gap and assist to explain how offshoring firms can develop their dynamic capabilities in collaboration with supplier firms.

The issue of creating dynamic capabilities for SCA, has received a considerable amount of attention recently in the strategic management field (Augier \& Teece, 2009). To create dynamic capability (DC), a firm has to integrate, build, and reconfigure internal and external competencies to address rapidly changing environments (Teece, Pisano, \& Shuen, 1997). Augier and Teece (2009) argue that a firm's DC stems from the particular capacity that firms have to shape, reshape, configure, and reconfigure idiosyncratic assets so as to respond to changing technologies and markets. Dynamic capabilities attempt to bridge these gaps by adopting a process approach. By acting as a buffer between the firm's resources and the changing business environment, dynamic resources help a firm to adjust its resource mix under offshoring framework and thereby can maintain the sustainability of the firm's competitive advantage, which otherwise might be quickly eroded. The DC perspective extends the RBV arguments by addressing how resources and capabilities can be created and how the current stock of resources and capabilities can be refreshed in changing environments (Ambrosini \& Bowman, 2009). The most salient issue is the relationship between the development of new capabilities and organizational performance (Sapienza, Autio, George, \& Zahra, 2006). They consider the critical point about configuring assets outside the firm's boundaries. Exploring the central issue of offshoring research - how firms address environmental challenge and manage the increasing complexity resulting from more and more different business functions and activities being offshored - could be a way to understand dynamic capabilities (Manning, Massini, \& Lewin, 2008; Massini, Perm-Ajchariyawong, \& Lewin, 2010). Alguezaui and Filieri (2011) argue that the offshoring strategy is a firm's core capability as well as the ability to coordinate its distributed activities for the purpose of enhancing long-term competitive advantage. Thus, the DCV can help managers to understand how to configure resources and capabilities in order to achieve advantages from the offshore outsourcing strategy. 
$8^{\text {th }}$ International Conference on Modern Research in

Management, Economics and Accounting

October 19-21, 2018 / Munich - Germany

2.2 Offshore outsourcing and organizational dynamic capabilities

Globalization, ease of communication, and logistics allow firms today to collaborate simultaneously with multiple partners across the globe. Competitive advantage (CA) in this new environment is the fleeting commodity that must be won again and again, and that requires continual disintegration and reintegration of routines, competences and capabilities of firms, with frequent reshuffling of structural, technological, financial, and human assets. Firms need to adjust their corporate designs and develop their value chain continuously in order to remain and move-up-the-value-ladder in the marketplace, which requires organizational capability to assure a continuous capability renewal process in the firm's extended boundary.

In a truly competitive environment, the only real source of competitive advantage is the ability to respond consistently to a changing market ecosystem with new products and ever improving competitiveness. Capabilities are a company's proficiency in the business processes that allow constantly distinguish itself along the dimensions that are vital to its customers. A firm's real core capability and perhaps its only sustainable one is its ability to design and redesign its value chain, resources, and capabilities configuration in order to continually find sources of maximum advantage (Fine, Vardan, Pethick, \& El-hout, 2002). By choosing offshore suppliers with complementary resources and competences, SMEs can develop such capabilities.

In offshore outsourcing, firms can learn, gain, assimilate, and co-develop capabilities from their interactions and strategic collaboration with offshore suppliers. Capability sourcing improves a company's competitive position by ensuring that processes and functions are obtained from the right source at the right cost. As sourcing matures, firms can leverage offshoring for more processes, in more countries, and to achieve a broader set of objectives, be it improved costs, quality, service levels, or capabilities. Internal capabilities are needed to secure an organization's future success (Roghé, Toma, Kilmann, Dicke, \& Strack, 2012).

Developing capabilities process is invisible and involves teams of resources working together. Despite the business process mapping, there is a very meager understanding of how people, machine, technology, various alliance partners, and organizational partners fit together to achieve a particular level of capability and the firm's performance. Strategic offshore outsourcing is a cooperative relationship between firms involved in sharing resources in pursuit of common goals. They may have formal agreements or informal dealings among themselves. They may or may not involve ownership links. Alliances may also be for the purpose of acquiring the partner's capabilities through organizational learning (Mowery, Oxley, \& Silverman, 1996). Developing organizational capabilities through offshore outsourcing is to create a conducive environment among the partner organizations to share and develop the know-how of each of the partners, which requires integrating knowledge of multiple organizations and its members. Firms can foster cooperation, exchange best-practice ideas, and involve employee engagement to fill the formal structures with life. By creating an environment conducive to collaboration, a firm can avoid adding dotted lines to its organization charts. By curtailing complexity in this way, the company is freer to respond more easily to changes in its markets. The development and sustenance of organizational capabilities is a continuous process, and managers might take it as a journey rather than a one-off project. In offshore outsourcing, a collaborative inter-firm resource, competences and capabilities configuration can create superior capabilities that lead towards SCA. 
$8^{\text {th }}$ International Conference on Modern Research in

Management, Economics and Accounting

October 19-21, 2018 / Munich - Germany

\section{METHODOLOGY}

The varieties of research orientations in offshore outsourcing and findings and importing theories from other fields imply that the field is still in its pre-paradigmatic stage, though this business strategy is widely used for at least last three decades. Case study is considered more appropriate when the study questions deal with the early phases of a new management theory when key variables and their relationships are being explored (Yin, 1994; Eisenhardt, 1989). Case studies therefore represent a methodology that is ideally suited to creating managerially relevant knowledge (Amabile, et al., 2001). Further, we are studying the offshore outsourcing of manufacturing SMEs. SMEs are in general less formalized and embody a higher level of tacit knowledge. These assumptions lead us to adopt the multiple case study method for data collection and analysis for this empirical investigation. Case studies serve different research purposes, such as exploration, theory building, theory testing, and theory extension/refinement (Voss, Tsikriktsis, \& Frohlich, 2002). We adopted an exploratory design, since developing dynamic capabilities, such as innovation capabilities, new market and product development, and flexibility development capabilities, through offshore outsourcing have not been addressed in the literature and measurement variables of these constructs are hardly assessable by explanatory studies. Case study is a very powerful method for building rich understanding of complex phenomena (Eisenhardt \& Graebner, 2007), that requires the capability to answer "how" questions (Yin, 2003; Pedersen, 2006). Multiple case study approach allows both an in-depth analysis of each case and the identification of contingency variables that distinguish each case from the others. Moreover, multiple case studies allow cross-case analysis and comparisons and generate more robust, generalizable, and testable interpretations of a phenomenon than single case study research (Eisenhardt \& Graebner, 2007). We are exploring how offshore outsourcing lead focal firms to develop dynamic capabilities for SCA. The SCA derives from distinctive resource combination unique for each firm. The idiosyncratic nature of distinctive resources and competences can only be captured by in-depth investigation such as case study. Following the choice of case methodology, we have also established the case selection criteria as well as the criteria of the interviewees. The following table 1 describes these criteria:

[Table 1 Here]

The study involves ten Quebec manufacturing SMEs from low and mid-low to mid-high level technological intensity firms drawn from across the industries to ensure the robustness of the analysis and to avoid the risk of deriving an "industry-specific" analysis. The distribution of the firms across the industry enabled us to compare and contrast the findings to get in-depth understanding of their offshore outsourcing activities and how these outsourcing strategies assist these firms to develop their organizational dynamic capabilities. These are the medium sized firms having between 20 and 500 employees. The descriptive statistics on the sample firms are given in the following Table 2:

[Table 2 here]

The selection of case firms was undertaken first from the database of Quebec manufacturing firms maintained by ICRIQ. However, the database does not distinguish the manufacturing 
$8^{\text {th }}$ International Conference on Modern Research in

Management, Economics and Accounting

October 19-21, 2018 / Munich - Germany

SMEs that are involved in offshore outsourcing activities. We then called companies with the pre-established criteria and if the firm fulfilled our criteria of selection and if a senior manager from production or in-charge of supply chain management (SCM)/outsourcing accepted our request for an interview, we fixed the interview date and time for duration of approximately 90 minutes. However, on several occasions, we had interviews of longer duration than the 90 minutes agreed upon while fixing the interview. We visited each company, took the interview face-to-face, and recorded it. We also took notes during the interview and added further explanations of principal themes and issues after the interview. Interviews comprised a set of semi-structured interviews with open questions for each of the relevant constructs in our conceptual framework. Secondary data was collected in the form of company reports and brochures as well as the websites of the sample SMEs. We also searched for information on the Internet, Eureka database, and local newspapers such as "Les Affaires," "Le Soleil", Montreal Gazette etc. to check for any articles on the selected firms. These secondary data helped us to understand the background information of manufacturing activities of these firms, the characteristics of the products, and their markets. The secondary data, to some extent, confirmed the information revealed by the interviewees. These secondary information sources were triangulated with the data drawn from the interviews to avoid post-hoc rationalization and retrospective interpretations, ensuring construct validity (Yin, 2003). The recorded interviews with the senior managers were transcribed and along with the secondary data were put in an electronic file for each firm. Following transcription, a telephone call was made to the interviewees in order to assess the outcomes and to gather missing data, if any. A comprehensive content analysis procedure was undertaken for each firm in all the documents in order to categorize and gather the principal items through an inductive approach, given at Table 3.

[Table 3 here]

The coding process started from the beginning of the data collection in order to get to the theory development mode faster and take advantage of subsequent field trips and interviews. We adopted four steps coding process: Initial coding, Axial coding, Selective coding, and theoretical coding. From the selective coding stage, we developed the categorizations of coding. Data categorization and contextualization (Miles \& Huberman, 1984) were applied to reveal unforeseen relationships between events and circumstances. We followed theory development cycles proposed by Carlile and Christensen (2005) by observation, classification and defining relationship. Explanation-building procedures were applied so that the relationships between the firm level and the transactions with the supplier firms were identified. These structured procedures for data collection and analysis, as well as the use of the semi-structured interview guide, helped enhance the reliability of the research (Yin, 2003).

\section{RESULTS AND DISCUSSIONS}

In our qualitative research, we focused on gathering mainly verbal data as well as information from publicly available documents and then analyzed in an interpretative manner, subjective, impressionistic, or even diagnostic. Case or field-derived data is, in general, subjective in 
$8^{\text {th }}$ International Conference on Modern Research in

Management, Economics and Accounting

October 19-21, 2018 / Munich - Germany

approach, but its objective is to understand human behavior and reasons that govern such behavior. The value of data depends on their usefulness in helping us to understand how the world works, identifying categories, making predictions and surfacing anomalies (Carlile \& Christensen, 2005). In reality, all research describes a situation and is, therefore, a case and all data are subjective (Carlile \& Christensen, 2005). We become subjectively immersed for objective outcomes in the subject matter of this research.

DCV literatures are mainly conceptual and this research field is still in the process of maturing. Though the literature recognizes the role of the external environment, the paucity of addressing dynamic capabilities development in a strategic alliance context such as offshore outsourcing is still prevalent. In our case study, we observed that there are two stages of the dynamic capabilities development process. The first stage deals with the antecedents of DC development and the second is the outcomes of collaborative activities between the offshoring client and supplier firms.

\subsection{Offshore outsourcing and evolutionary process of dynamic capabilities}

Offshore outsourcings SMEs follow an evolutionary path for developing their dynamic capabilities in collaboration with their offshore suppliers. They follow the "three-S" model of sensing, seizing, and shaping (Augier \& Teece, 2009), given at the table 4. Following the sensing of the opportunities and threats in the market, offshoring SMEs exploit the sensed opportunities and fend off the threats by aligning and reconfiguring resources and competences with those from the supplier firms.

$$
\text { [Table } 4 \text { Here] }
$$

\subsection{Offshore outsourcing and dynamic capability development}

Offshore outsourcing focal firms configure their internal resources and competences with those from the supplier firms in order to develop their specialization by focusing on core activities and develop their innovativeness for product, process, marketing, and organizations or management given at Table 5. The new configurations render focal firms more flexible and fit for the dynamic environment.

\subsection{Cross-case analysis}

[Table 5 here]

In the within case analysis phase, we aimed to create micro-theories of the phenomena, that is, developing organizational dynamic capabilities through offshore outsourcing in each case and to explore adequacy of an emerging cross-case pattern to each individual case. During the crosscase analysis, we aimed at creating an overarching, integrative theory that is compatible with all cases. Cross-case analysis shows that low-tech manufacturing SMEs offshore higher rate of activities and focus mostly on core activities, such as conception and designing, marketing, and logistics. Our discussions with the managers reveal that offshore outsourcing follows gradual approaches to offshore activities starting from standardized non-core activities and gradually 
$8^{\text {th }}$ International Conference on Modern Research in

Management, Economics and Accounting

October 19-21, 2018 / Munich - Germany

moving to offshore higher-technology intensity activities to supplier firms. Cross-case analysis also shows that for some variables of the constructs where outsourcing focal firms could develop both their dynamic capabilities and efficiency and some others they adopt only the efficiency strategy. Most offshoring firms in our sample get limited feedback for new product development and developing markets in the suppliers' countries or in neighboring countries. On the other side, most companies said that they could better focus on their core activities after offshoring part of their activities. Most companies could improve their specialization, cover higher market share, and improve overall productivity of their firms following offshore outsourcing. The overall trend shows that offshoring firms get more concentrated on fewer suppliers than looking for new suppliers or dispersed among many suppliers as they develop their understanding of the outsourcing process, opportunities and challenges. Inter-industrial differences of innovation show that the relatively high-tech firms have more joint development teams and informal exchanges on R\&D than the relatively lower-tech firms. High-tech firms also have higher rate of outsourcing of near-core activities such as design and conception of the product. Further analysis shows that the overall competitiveness of SME manufacturing depends on both technical fit and evolutionary fit. Close collaboration with the supplier firms contributes both technical and evolutionary fit; however, the contribution to the latter is more than that to the former. The above cases can be further categorized into three, given at Table 6, according to the level and pace of dynamic capability development.

4.5 Dynamic capabilities development process and SCAs

Offshore outsourcing allows firms to have access to many complementary resources and capabilities that assist these firms to improve their competitiveness and survivability in the competitive marketplace. Offshoring allows the manufacturing SMEs to put more emphasis on core activities, improve the innovation capabilities, develop new products and markets, and increase organizational flexibility, and these enhanced capabilities lead towards SCAs.

\subsubsection{Offshore outsourcing and higher concentration on CC}

Core competency is the "raison d'être" for the firm in a competitive marketplace. CC are capabilities that provide competitive advantage for a firm, help firms to gain access to key markets, and deliver distinctive value to customers(Prahalad \& Hamel, 1990; Barney, 1991). From a management perspective, firm's core competency refers to the ability to sustain development, asset value appreciation, and performance improvement. Firms need to acquire or have access to external sources of capability related to its core business in order to sharpen the tool to respond to new competition of different types and characteristics. External resources create value once integrated with internal resources. The integration of core business and management of offshoring holds the key for a firm's competitiveness in offshoring production system. The more sophisticated the market, the more intense competition companies might face, higher the level of core competency will be (Guoqiang, Shen, Peng, Yao, \& Jun, 2005).

Focusing more on CC makes them more specialized and capable of contributing to SCA. According to Kotabe, Mol, \& Kethar (2008), offshoring leads to an increased focus on core 
$8^{\text {th }}$ International Conference on Modern Research in

Management, Economics and Accounting

October 19-21, 2018 / Munich - Germany

competency, thereby improving effectiveness. Offshoring is a powerful way to rapidly build capabilities and reap the benefits of increased specialization (Hagel \& Brown, 2005). Savings of time and resources from offshore outsourcing allows firms to invest more in CC and allows corporate managers to have more managerial focus on core activities. Managing offshoring and linking it with internal resources and core business opens up new ways for companies to develop CC. The key is to transform external resources into the firm's core competency, consider as hybrid-core competences. Offshoring suppliers contribute to support services of the $\mathrm{CC}$ and thus accelerate further development of the core competency. By establishing offshoring partnership with a complementary supplier firm, offshoring SMEs get access to the process capability and the capabilities of quality assurance, fast response, and service awareness that come with the supplier (Guoqiang, Shen, Peng, Yao, \& Jun, 2005). Therefore, it is of strategic importance for the firm to transform from traditional arm's-length relation of offshore outsourcing to partnership-oriented offshoring. By doing this, SMEs develop their core competency by integrating external resources. Offshoring SMEs develop a new set of rules and concepts for management \& operation and build trust with an attempt to create a "win-win" case and shared development goals. Quality, cost, and time (rapid response and flexibility) remain the most salient issues in offshore outsourcing production systems. It allows firms free up scarce resources and capabilities to invest in the core competency activities. Focusing on CC and leveraging capabilities from other offshoring supplier firms allows firms to specialize in $\mathrm{CC}$ on one hand and give access to the specialized capabilities from the best-in-class offshore suppliers on the other hand.

Data from the selected ten manufacturing SMEs shows that offshore outsourcing allowed them to disperse some activities to the outsourcing supplier firms and enabled them to save investments in those activities in both managerial and financial terms. The savings allowed senior managers to concentrate more on strategic activities and planning. They could divert their attention toward the activities that create higher value. Firm SI pointed out, "We are strengthening our core business, renewing our focus on discontinuous innovations while partnering for some activities with our offshoring suppliers [and we introduced] "learn, do, and teach approach with our suppliers." Outsourcing allowed firms to reduce the number of components or articles they used to make before starting outsourcing. One of the fundamental issues that were revealed in our discussion with the managers was that they started with outsourcing non-core repetitive activities and progressed slowly to outsource activities that require higher technologies and expertise toward near-core activities. This was gradual and some firms (RG, PW, IR) have outsourced a considerable share of their manufacturing activities and concentrated in the few high-valued activities in their headquarters in Canada (Quebec). The manager of RG, the highest level of outsourcer among the ten firms, mentioned "Offshoring manufacturing activities enabled us to invest more on high value-added activities in design and conception and also in the marketing and logistics." The supply chain manager of IR said that they practically become an integrator of components sourced from multiple outsourcing suppliers from the developed as well as emerging countries. Their $\mathrm{CC}$ become in integration of different systems rather than producing any particular component or product. The VP of PW mentioned that outsourcing allowed them to focus more on marketing and on new ideas for 
$8^{\text {th }}$ International Conference on Modern Research in

Management, Economics and Accounting

October 19-21, 2018 / Munich - Germany

product development. Outsourcing also enabled firms to invest more on their $\mathrm{R} \& \mathrm{D}$ or in the engineering department where they develop the new product or modify, change and improve the existing products and components. However, some of the sample firms could not increase their investment in their engineering department or in their core activities due to the financial crises during the 2008-2011 period. But they acknowledged that the situation could be worse if they could not procure the components from their outsourcing suppliers during the economic crises when they were not in a position to invest in the manufacturing infrastructure at their domestic plants. Thus, we can make the first proposition that:

\section{Proposition 1. Offshore outsourcing of Manufacturing SMEs enhances focus on organizational core competencies that leads toward higher specialization and superior capabilities.}

4.5.2 Offshore outsourcing and developing innovation capabilities

Innovation is a company's commitment to creating and introducing new products, new production processes, and management systems (Vaccaro, Jansen, Van Den Bosch, \& Volberda, 2012). Innovation is the implementation of a novel and manageable (Wagner \& Busse, 2008) idea into a new product or new process (Schilling \& Phelps, 2007). Innovation may involve existing or new knowledge (Schoonhoven, Eisenhardt, \& Lyman, 1990), and may occur formally or informally (Harrison \& Samson, 2002).

In a rapidly evolving business environment and reduced product life cycle, SMEs are facing challenges from competitors both from low-cost countries (LCC) and high-cost countries (HCC). One of the ways by which the manufacturing SMEs from the developed countries like Canada can survive and sustain their competitiveness is by improving their innovativeness in terms of product, process, market, and organization by developing and hastening their innovation capabilities. That includes the skills, knowledge, and management techniques needed to create, change, improve, and commercialize successfully "artifacts," such as products, services, equipment, processes, and business models (Drucker, 1985, p. VIII). With collaboration from offshoring suppliers, SMEs develop their innovative capabilities faster and more efficiently. Collaboration and exchanges of knowledge through transferring expertise and skilled personnel between the offshoring client and supplier firm enhance and hasten the innovation process of the offshoring SMEs. Offshoring suppliers' innovations take the form of new products, new production methods, new markets, new sources of supply, or new business processes. Any of these innovation capability factors affect the performance of the offshoring SMEs in their innovation process (Naghavi \& Ottaviano, 2009). Access to skilled human capital and science and engineering talent facilitate the product development process. The enhanced capabilities have a significant impact on timing and amplitude of innovation at offshoring SMEs. These multiple facilities allow offshore outsourcing firms to reduce their innovation cycle times and cost, and decrease investments and risks by $60 \%$ to $90 \%$ (Quinn, 1999).

Manufacturing SMEs are constrained in terms of size and resources to invest in innovation capabilities development. The manufacturing supplier firms are, in general, large enterprises with 
$8^{\text {th }}$ International Conference on Modern Research in

Management, Economics and Accounting

October 19-21, 2018 / Munich - Germany

huge investment in equipment and skilled manpower and offer their services to large offshoring companies from developed countries. Offshoring to large supplier firms allows SMEs to have access to new technology and innovations. The VP of SCM of the firm CN mentioned, "We encourage our people from the $R \& D$ and product development department to share the development process with our suppliers and get suggestions from them. We trust the partners with whom we work and we think it is easy to be open and honest with long-term suppliers/partners." Supplier firms thus contribute to overall development of innovation capabilities. Moreover, when offshoring focal firms send their "tooling" and "prototypes" to the supplier firms and ask them to produce those goods; they come up with refinement of the tooling and improve manufacturability of the product. In case of a "Prototype," supplier firms from the emerging countries make them with real material and outsourcing firms can observe "real product with real materials" (PW vice-president) "rather than the $3 D$ printing that we do in developed countries." Tooling and prototyping are very popular among the offshoring focal firms to send to the outsourcing suppliers and gain valuable innovative suggestions and contribute to improving these activities for better quality goods production. "Offshoring to the advanced emerging countries gave us access to qualified personnel and extended test and trial facilities, which lead to improved efficiency and service level processes, and increase the speed to market of our products" (VP, PW). Offshoring supplier firms contribute greatly to manufacturability through improving the production process of products or components conceived by the focal firms. According to the firm AV, "It's very important to the vertical relationship with our suppliers that the innovation process is often supplier led and not from us." However, in order to reach the level of getting this feedback from the outsourcing suppliers, focal firms need to integrate them into the product conception and design stages. The VP of the firm RI mentioned, "We have clear aims and objectives that both parties understand and we invest our collective efforts to achieve our goal and reward accordingly." However, this is not always practiced by the offshoring focal firms due to the fear of losing intellectual property to the supplier firms. At the same time, some of the SMEs revealed that they outsource standardized products and components that do not have many intellectual property issues. Director of the international operations of FP said, "I am always having my attention on every production process in our suppliers' factories and we have excellent formal and informal channels of communications and knowledge transfers between our partners and we manage our intellectual properties together." Data show that offshoring firms could reap advantages from the capabilities of their supplier firms and their investment in R\&D and develop new way of making the same product and/or improve the process. However, this moving-up-the-value-ladder is mostly incremental than radical changes. Thus, our second proposition is as follows:

Proposition 2. Offshore outsourcing enhance collaboration, coordination and sharing interfirm resources, competences and capabilities to perform outsourcing activities that contribute to developing new way of performing the activities and accelerate and co-develop their innovation capabilities.

\subsubsection{Offshore outsourcing and developing new products and markets}


$8^{\text {th }}$ International Conference on Modern Research in

Management, Economics and Accounting

October 19-21, 2018 / Munich - Germany

With technological advancement and globalization, products continue to become more technically complex but increasingly sliceable and re-integrable in scope, facilitating distributed production in a networked virtual environment (Contractor, Kumar, Kundu, \& Pedersen, 2010) and contribute to increased possibilities of developing new configurations and new products. As developing in-house capabilities and acquiring firms with the specific capabilities are time consuming and costly for SMEs, cooperating with offshore supplier firms to gain access to certain capabilities and know-how is especially pertinent in the current, increasingly volatile business environment. Reduced product life cycle, rapid changes in the marketplace, scarce resources, and capabilities force the SMEs to have access to their offshore supplier's capabilities for faster response and rapid new product development (NPD) through integrating innovative process and components from the suppliers. The current rate of technological change is challenging many manufacturing firms' capabilities, and they are seeking the help of offshoring suppliers with the development and application of critical but non-core technologies in their new products (Handfield, Ragatz, Peterson, \& Monczka, 1999). Offshore outsourcing as an operation mode is both a source of cost savings as well as a way to acquire know-how for a firm (Kotabe, Mol, \& Kethar, 2008). Offshoring supplier firms provide intermediate components or systems that create competitive advantages in the product development process such as applicationspecific inputs, and proprietary materials (Huang \& Chu, 2010). Past experiences and incentive public and private policies enabled emerging country firms (ECF) to develop technology, innovation, and system improvement capabilities. By accessing to these capabilities, offshoring SMEs improve product quality and reduce cost. Offshoring supplier firms help them in generating new ideas for differentiating products, offer solutions to technical design problems, and communicate insights of emerging global markets and their varying needs. Collaboration with the offshoring supplier is a fast, low-risk, and flexible way to try out new markets without fully committing the resources or developing needed capabilities. NPD research points out that if firms want to announce new products effectively and efficiently, they should obtain the involvement and support of offshoring suppliers, contributing to new product success (Petersen, Handfield, \& Ragatz, 2005). Thus, globalization and technological advancement are deepening the need for SMEs to develop long-term partnership with the offshoring supplier firms in creating new products or redefined products in the shortest possible time with minimum investments and shared risks. Offshore outsourcing also help SMEs to have exposure to the foreign market via their offshoring supplier and become familiar of that market that enable them to expand there along with the regional neighbouring markets.

Offshoring SMEs integrate suppliers into the design phase of the product in order to reduce development and production time and offer speedy response to changing customer demand. Building credible relationships with offshoring suppliers is particularly beneficial for long-term partnership. Suppliers provide innovative product or process technologies that are critical to the novelty of the final product (Swink \& Mabert, 2000; Handfield, et al., 1999; Azadegan, Kevin, Carter, \& Carter, 2008). Consistency in business approaches and frequent contacts are prerequisites for long-term relationships. The best-in-class offshoring supplier firms provide ideas and design concepts early in the fuzzy front end of product development (Swink \& Mabert, 2000). Offshoring suppliers also enhance offshoring SMEs' new product development (NPD) 
$8^{\text {th }}$ International Conference on Modern Research in

Management, Economics and Accounting

October 19-21, 2018 / Munich - Germany

processes by offering rapid and "production type" prototyping, tool design, and product testing. On the other hand, managers must ensure that suppliers are creative, technically skilled, and contribute in a team environment. Offshoring supplier firms can also provide knowledge of or access to foreign markets, regulatory requirements, and local customs. Tapping into their capabilities also gives access to skills or talents not available in the home markets, especially engineering talents. With the integration of the offshoring supplier's capabilities, offshoring SMEs are able to design products that cater to the distinct tastes and needs of different markets. The mass customization is possible by collaborating with different suppliers with particular capabilities. Offshoring SMEs also have local presence through their partnership with suppliers without much investment in foreign market development. Moreover, offshore suppliers also absorb cyclical demand, economic swings, and disruptions due to labor strikes or natural disasters. The success and failure of the final product depends not only on the capability of offshoring SMEs, but also on the manufacturing, research, and development capabilities of suppliers. Knowledge and capabilities of suppliers contribute to SMEs' competency improvement. Offshoring suppliers' participation in the NPD process help reduce cost, reduce concept-to-customer development time, improve quality, and provide innovative technologies that help capture market share.

Offshoring firms in our sample were mostly low- to mid-tech industries. That means the products of these firms were not very sophisticated and were mostly modular products. That implies that the components were modularizable and outsourced to the supplier firms and taken back to reintegrate to make the complete product. For some modules, outsourcing firms proposed different components to integrate into the product. As the CEO of ER said, "We have sent our design to our Taiwanese outsourcing partner and they proposed a new way of making the component" with similar utility but cheaper. However, outsourcing firms did not propose any completely new product. The idea was mostly originated from offshoring focal firms. On the other hand, outsourcing allowed the offshoring firms to avail the low-cost development of tooling and prototyping and that allowed the focal firms to take more risks for conceiving and developing more new products. In this case, the contributions of the outsourcing firms were indirect. Outsourcing further aided the new product development process by accelerating the process of the new product development cycle. The manager of the firm PW said, "Together with our suppliers, we accomplished more than what one of us can do on our own. Together we increased our market share, developed new products faster, and won many customers. It is a win-win partnership with less financial investment in this time of crises."

We have found also that the manufacturing SMEs could develop new markets through offshoring to supplier firms, especially to China. Due to the emergence of China as a world factory, many companies outsource to China. Some of those firms in our sample send their core components to China for assembling with components produced in China and deliver their goods to the distributors in China and name it as "Made-in-Canada, delivered in China" (PW). The distributors have other suppliers in China and receive the final goods from all their Chinese suppliers in China for economy of scale concern. The distributor may bring those products to North American markets or other destinations. Thus, outsourcing is shifting the place where the 
$8^{\text {th }}$ International Conference on Modern Research in

Management, Economics and Accounting

October 19-21, 2018 / Munich - Germany

transactions take place, though it does not open new market that much in real term in the supplier countries. However, some of our sample firms found markets in the supplier countries and/or neighboring countries, though it is still in the beginning. For example, our sample firms IR, MR, and ER found new markets in their outsourcing countries. IR offers building a halal slaughtering system and do outsourcing to China among others and it found clients in Malaysia. However, this is not the case with all the firms in our sample. In terms of expansion in local markets, outsourcing provides economy of scale both through access to the manufacturing facilities of the supplier firms and by saving investment in fixed infrastructure. Thus, outsourcing contributes to market development. Thus, the third proposition is as follows:

Proposition 3. Manufacturing offshore outsourcing allows firms to collaborate for new product development and new market development.

4.5.4 Enhanced organizational flexibility

Rapidly changing business environment and market volatility require fast adjustment of firms to the prevailing market situation. Flexibility is considered solely as an adaptive response to environmental uncertainty (Gupta \& Goyal, 1989; Golden \& Powell, 2000). A firm can encourage customers to see the benefits of shorter lead times or more frequent new product introductions and then provide these higher levels of service through superior manufacturing flexibility and create more uncertainties for its rivals and establish a powerful competitive advantage for the firm (Gerwin, 1993). Krijnen (1979) argued that strategic flexibility possesses elements that prepare for the foreseen and provides avenues to react to the unforeseen. Many authors classify manufacturing flexibility by variations such as process, product, or production volume (Chang, Lin, \& Sheu, 2002).

Organizational flexibility becomes increasingly critical for firms to remain competitive in the marketplace. SMEs offshore business areas to achieve greater flexibility and to gain greater ability to respond nimbly. It is critical to be able to respond to changing market conditions and a competitive environment. Besides efficiency and effectiveness improvements, flexibility is a source of value on its own in offshoring deals. Multidimensional features and multilevel organizational flexibility add complexity to empirical measures. Flexibility dimensions are both market as well as manufacturing process oriented. The dimensions of flexibility is also be classified in terms of time and range (Golden \& Powell, 2000). The temporal dimensions can be described in terms of the length of time that it takes an organization to respond to environmental changes. The range dimension of flexibility is the degree to which an organization adapt to foreseeable and unforeseeable changes.

Flexibility in manufacturing is a critical source of competitive advantage. Offshoring creates a flexible networked production system. Offshoring allows firms to have more flexibility in the step-up or step-down of production volume, depending on market volatility in demand, without incurring losses. This capability leveraging strategy enables offshoring SMEs to switch, at short notice, between the products that suppliers produce, as well as to change suppliers if needed. The hybrid governance structure of offshoring alliances creates the flexibility necessary to promptly seize opportunities in a rapidly changing market (Veilleux, et al., 2012). That means the network 
$8^{\text {th }}$ International Conference on Modern Research in

Management, Economics and Accounting

October 19-21, 2018 / Munich - Germany

provides greater flexibility than that achievable through vertical integration by a single organization. One main reason for this is that individual firms in the network can be added or dropped rapidly as required. The network implies a narrower range of output at the level of the individual firm, but a substantial degree of flexibility at the level of the network (Sayer, 1989). Thus, an individual organization in a network obtains lower internal flexibility while simultaneously obtaining increased external flexibility. Offshoring allows SMEs to source intermediary components from competent suppliers around the globe that render the SMEs more flexible.

Offshoring enables firms to be flexible in a way that can follow and adjust to the market trends. It allows manufacturing SMEs to transform fixed cost (capital investment, etc.) into variable costs and render firms more flexible. Data from our sample SMEs show that offshoring enabled them to adjust their production volume according to the market trends. Modular production allowed firms to act on different parts of their production and processes when needed without completing the whole process of the production system. Manufacturing SMEs are no more constrained by their shortages of investment in capital equipment and immobile infrastructure. For some of the sample SMEs (IR, PW, MR) we found also that they do not find enough qualified technicians for expanding their production facilities here in Quebec and outsourcing facilitated them to have access to the required low-cost/high-value knowledge. They also revealed that some of their large outsourcing suppliers have also delayed the delivery of their outsourcing goods and components during the financial crises and offered also indirect credit by allowing the payment after receiving from the clients (IR). Thus, offshore outsourcing enabled manufacturing SMEs to be more flexible and leaner. Thus, our fourth proposition is:

Proposition 4. Offshore outsourcing allows manufacturing SMEs to collaborate and share expertise and capabilities for performing complementary production activities together and develop capabilities to follow market trends and adjust fast accordingly.

Dynamic capabilities all together enable offshoring SMEs to survive and sustain in the marketplace by improving their competitiveness. Thus we can make our fifth proposition:

Proposition 5: Dynamic capabilities lead offshoring SMEs to achieve sustainable competitive advantage (SCA).

Based on our findings and analysis, we hence propose the following framework of offshore outsourcing, organizational dynamic capabilities, and SCAs. Inter-relationship among the factors are presented at the figure 1.

\section{CONCLUSION}

Firms need resources, know-how and have the competencies of coordinating and configuring dispersed inter-firm and intra-firm resources and competences in order to create a network capability so that firms can compete in the global marketplace and create SCA. Offshore outsourcing collaboration among the complementary firms with heterogeneous resources and capabilities create the win-win case for developing capabilities advantageous for both client and 
$8^{\text {th }}$ International Conference on Modern Research in

Management, Economics and Accounting

October 19-21, 2018 / Munich - Germany

supplier firms. This paper shed light on how offshoring enables SMEs to develop their organizational dynamic capabilities that lead them towards achieving SCA in the marketplace. Liberating resources from offshoring allows SMEs to invest and focus more on their core activities. Moreover, offshoring those activities where SMEs do not have comparative advantage, help the remaining activities to achieve higher productivity. Offshoring also allowed the SMEs to accelerate their innovation process by introducing better quality products, introducing a new product, or acquiring a new process of production, and thus renders the SMEs more competitive in the marketplace. Accessing the resources and capabilities from offshore supplier networks renders the offshoring SMEs more flexible in terms of time, frequency, and volume of production of their products. Offshore outsourcing allows SMEs to reconfigure their resources and capabilities, and redesign their value chain with collaboration from supplier firms and leads them to become more competitive, sustainable, and agile in the volatile business ecosystem. Developing a web of best performers through offshore outsourcing partnership enhances the competitiveness of the value chain and enables SMEs to compete with both large firms and other SMEs, especially in the niche market. Manufacturing SMEs in developed markets are facing steep competition from emerging countries, and offshoring is one of the "level playing field" in the marketplace. This study contributes toward better understanding of the SMEs' offshoring and how the offshoring enable them to develop dynamic capabilities. For low-tech and low-to-mid tech firms, offshore outsourcing enable them to keep some activities in the home countries and compete in the world market on similar footings thanks to procuring intermediate components and other services from the low-cost-countries (LCC).

The study also presents the theory development process and highlights the managerial strategies of how SCAs are created from organizational dynamic capabilities developed in collaboration with supplier firms. Application of the DCV to manufacturing offshoring SMEs is the fundamental contribution to this field of knowledge. This study shows managers how to build, integrate, and reconfigure their internal as well as external resources for distinctive organizational capabilities for SCAs. This paper, thus, is very promising for both theory building process as well as professional managers' understanding.

While the offshoring supplier firms enhance the specialization and focus on core activities and improve innovativeness and flexibility, only two cases demonstrated that the familiarity of the offshoring host countries' can open new markets for their products. The same can be concluded for new product development (NPD). In a world of hyper-competition and multiple levels of exchanges and partnerships, manufacturing firms need to develop ambidexterity (the art of thriving in complex environments), where they are capable of exploring new ways of doing things along with exploiting existing ones. In our research, we found the manufacturing SMEs are involved both exploring and exploitative offshore outsourcing. Integrating these two approaches not only enable them to develop further their capabilities but also enabling the suppliers to develop their expertise in some cases and thus developing a long term partnership. In a dynamic environment, manufacturing firms need to pass through continuous transition between styles and strategies for introducing new products and developing existing products and targeting both emerging and developed markets. Organizational dynamic capabilities are self-tuned to acquire experience and changing business environment and allow firms to explore new opportunities and exploit existing ones and enable them to thrive under uncertainty and rapid 
$8^{\text {th }}$ International Conference on Modern Research in

Management, Economics and Accounting

October 19-21, 2018 / Munich - Germany

change. In brief, strategic offshore outsourcing enables SMEs to become evolvable enterprises that recombine, reconfigure, and co-develop inter-firm resources for SCA. Previous research addressed the developing dynamic capabilities as an internal organizational issue or in an equity based partnership following a substantialist approach that most methodological tools are focused on and best suited in identifying convenient sources data that can be easily counted and categorized more readily than the relational properties that exist between individuals, groups or organizations in a given social space over time (Bourdieu, 1989). The current study showed the developing dynamic capabilities in a relational approach with the supplier firms in a non-equity based partnership. This is one of the fundamental contributions of this paper. Future research with longitudinal data needs to evaluate the extent of dynamic capabilities development by manufacturing SMEs offshoring. Future research can also address the strength of the collaboration in the framework of offshore outsourcing and how the degrees of the collaboration affect the dynamic capabilities development process. One of the limitations of this research is the generalizability of the results from the case study, though many researchers in the field advocate analytical or theoretical generalization instead of statistical generalization. Our results are presented in the wider framework of the dynamic capabilities development process in an offshore outsourcing context to fulfilling the requirement of theoretical generalization.

\section{REFERENCES}

Alguezaui S., \& Filieri, R. (2011). Innovation across Tech-Firm's Boundaries: a KnowledgeBased View, In Contractor, F., Kumar, V., Pedersen, T. and Kundu, S. (Eds.), Outsourcing and Offshoring of Business Activities: Determinants, Implications and Challenges, Cambridge University Press, 210-238.

Ambrosini, V., \& Bowman, C. (2009). What are Dynamic Capabilities and are They useful Construct in Strategic Management? International Journal of Management Reviews, 11(1), 29- 49.

Augier, M., \& Teece, D.J. (2009). Dynamic capabilities and the role of managers in business strategy and Economic performance. Organization Science, 20(2), 410-421.

Azadegan, A., Kevin, J. D., Carter, P.L., \& Carter, J.R. (2008). Supplier innovativeness and the role of interorganizational learning in enhancing manufacturing capabilities. Journal of Supply Chain Management, 44 (4), 14-35.

Barney, J.B. (1991). Firm Resources and Sustained Competitive Advantage. Journal of Management, 17, (1), 99-120.

Bertrand, O. (2011). What goes around comes around: Effects of offshore outsourcing on the export performance of firms. Journal of International Business Studies, 42(2), 334-344.

Bourdieu, P. (1989). Practical Reason, Stanford: Stanford University Press.

Carlile, P. R., \& Christensen, C. M. (2005). The Cycles of Theory Building in Management Research. Harvard Business School. http://citeseerx.ist.psu.edu/viewdoc/download;jsessionid=31018743BDFDBFF6549A544C9 569ED14?doi=10.1.1.335.2372\&rep=rep1\&type=pdf

Chang, S.C., Lin, N.P. \& Sheu, C. (2002). Aligning manufacturing flexibility with environmental uncertainty in high-tech industry, International Journal of Production Research, 40(18), 4765-4780. 
$8^{\text {th }}$ International Conference on Modern Research in

Management, Economics and Accounting

October 19-21, 2018 / Munich - Germany

Contractor, F. J., Kumar, V., Kundu, S. K., \& Pedersen, T. (2010). Reconceptualizing the firm in a world of outsourcing and offshoring: The organizational and geographical relocation of high-value company functions. Journal of Management Studies, 47(8), 1417-1433.

Di Gregorio, D., Musteen, M., \& Thomas, D. E. (2008). Offshore outsourcing as a source of international competitiveness for SMEs. Journal of International Business Studies, 40(6), 969-988.

Drucker, P.F. (1985). Innovation and Entrepreneurship: Practice and Principles, Harper Business Edition. PMCid: PMC1346743

Eisenhardt, K. M., \& Graebner, M. E. (2007). Theory building from cases: opportunities and challenges. Academy of management journal, 50(1), 25-32.

Eisenhardt, K. M. \& Martin, J.A. (2000). Dynamic capabilities: what are they? Strategic Management Journal, 21 (10-11), 1105-1121.

Elango, B. \& Fried, V. H. (1993). Flexible manufacturing technologies: implications for competition between small and large firms. Journal of High Technology Management Research, 4(2), 241-54.

Fine, C. H., Vardan, R. Pethick, R. \& El-hout, J. (2002). Rapid-response Capability in Value chain design, MIT, Sloan Management Review, 43(2).

Gerwin, D. (1993). Manufacturing Flexibility: A Strategic Perspective, Management Science, 39 (4), 395-410.

Golden, W. \& Powell, P. (2000). Towards a definition of flexibility: in search of the Holy Grail? Omega .The International Journal of Management Science, 28, 373-384.

Guoqiang, Y., Shen, X., Peng, L., Yao, C. \& Jun, X. (2005). The Link. http://www.ceibs.edu/link/latest/images/20050630/1361.pdf (Retrieved on 10th May, 2012).

Gupta, Y. P. \& Goyal, S. (1989). Flexibility of Manufacturing Systems: Concepts and Measurements. European Journal of Operation Research, 43, 119-135.

Gulbrandsen, B., Sandvik, K., \& Haugland, S.A. (2009). Antecedents of vertical integration: Transaction cost economics and resource-based explanations. Journal of Purchasing and Supply Management, 15 (2), 89-102.

Hagel III, J. \& Brown, J.S. (2005). Productive Friction: How difficult business partnership can accelerate innovation, Harvard Business Review, (February 2005).

Handfield, R. B., Ragatz, G. L., Peterson, K., \& Monczka, R. M. (1999). Involving suppliers in new product development? California management review, 42, 59-82.

Harrison, N. \& Samson, D. (2002). Technology management: Text and international cases. McGraw-Hill.

Helfat, C. E., Finkelstein, S., Mitchell, W., Peteraf, M. A., Singh, H., Teece, D. J., \& Winter, S. G. (2007). Dynamic capabilities: Understanding strategic change in organizations. London: Blackwell.

Huang, Yen-Tsung \& Chu, Wenyi. (2010). Enhancement of product development capabilities of OEM suppliers: inter- and intra-organisational learning. Journal of Business and Industrial Marketing, 25(2), 147-158.

Javalgi, G., Dixit, A. \& Scherer R. (2009). Outsourcing to Emerging Markets: Theoretical Perspectives and Policy Implications. Journal of International Management, 15, 156-168. 
$8^{\text {th }}$ International Conference on Modern Research in

Management, Economics and Accounting

October 19-21, 2018 / Munich - Germany

Jensen, P. D. Ø., \& Pedersen, T. (2011). The economic geography of offshoring: the fit between activities and local context. Journal of Management Studies, 48(2), 352-372.

Jiang, B., Belohlav, J. A., \& Young, S. T. (2007). Outsourcing impact on manufacturing firms' value: Evidence from Japan. Journal of Operations Management, 25, 885-900.

Jones, R. W. (2008). Production fragmentation and outsourcing: General concerns. The Singapore Economic Review, 53(03), 347-356.

Kotabe, M., Mol, M. J., Murray, J. Y., \& Parente, R. (2012). Outsourcing and its implications for market success: negative curvilinearity, firm resources, and competition. Journal of the Academy of Marketing Science, 40(2), 329-346.

Krijnen, H.G. (1979). The flexible firm. Long Range Planning, 12: 63-75.

Lewin, A.Y., Massini, S. \& Peeters, C. (2009). Why are companies offshoring innovation? The emerging global race for talent. Journal of International Business Studies, 40: 901-925.

Liesch, P.W., Buckley, P.J., Simonin, B.L.,\& Knight, G. (2012).Organizing the Modern Firm in the Worldwide Market for Market Transactions. Management International Review, 52:3-21.

Manning, S., Massini, S. \& Lewin, A.Y. (2008). A dynamic perspective on next-generation Offshoring: the global sourcing of science and engineering skills. Academy of Management Perspectives, 22(3), 35-54.

Massini, S., Perm-Ajchariyawong N, \& Lewin AY. (2010). Role of corporate wide offshoring strategy in directing attention to offshoring drivers, risks and performance. Industry and Innovation, 17, 337-371.

McDermott, C. M., \& O'Connor, G. C. (2002). Managing Radical Innovation: An Overview of Emergent Strategy Issues, The Journal of Product Innovation Management, 19, 424-438.

Miles, M. B., \& Huberman, A. M. (1984). Drawing valid meaning from qualitative data: Toward a shared craft. Educational researcher, 13(5), 20-30.

Mohiuddin, M., \& Su, Z. (2013). Offshore outsourcing of core and non-core activities and integrated firm-level performance: An empirical analysis on Quebec manufacturing SMEs. “M@n@gement." http://www.management-aims.com/about_en.html

Mowery, J., Oxley, E., \& Silverman, B.S. (1996). Strategic Alliances and Inter-firm Knowledge Transfer. Strategic Management Journal, 17(winter special issue): 77-93.

Naghavi, A. \& Ottaviano, G. (2009). Offshoring and product innovation, Economic Theory, 38(3): 517-532.

Pedersen, T. (2006). Managing global offshoring strategies: A case approach. Copenhagen Business School Press DK.

Petersen, K.J., Handfield, R.B., \& Ragatz, G.L. (2005). Supplier integration into new product development: Coordinating product, process and supply chain design. Journal of Operations Management, 23: 371-388.

Prahalad, C. K. \& Hamel, G. (1990). The Core Competence of The Corporation, MA: Harvard Business Review, May-June.

Quinn, J.B. (1999). Strategic Outsourcing: Leveraging Knowledge Capabilities. Sloan Management Review, 40(4): 8-21.

Rashid, M. M., \& Al-Azad, M. S. (2013). Relocating Low-to-Medium Tech Manufacturing Activities to Developing Countries: Empirical Analysis of Taiwanese and South Korean 
$8^{\text {th }}$ International Conference on Modern Research in

Management, Economics and Accounting

October 19-21, 2018 / Munich - Germany

Manufacturing Outsourcing to Bangladesh. Transnational Corporations Review, 5(2), 1629.

Roghé, F., Toma, A., Kilmann, J., Dicke, R. \& Strack, R. (2012). Organization of the futureDesigned to win: Organizational capabilities Matter. Boston consulting Group.

Sapienza, H. J., Autio, E., George, G., \& Zahra, S. A. (2006). A capabilities perspective on the effects of early internationalization on firm survival and growth. Academy of Management Review, 31(4), 914-933.

Sayer, A. (1989). Post-Fordism in question. International Journal of Urban Region, 13, 66695.

Schilling, M. A., \& Phelps, C. C. (2007). Inter-firm collaboration networks: The impact of large-scale network structure on firm innovation. Management Science, 53, 1113-1126.

Schoonhoven, C.B., Eisenhardt, K.M., \& Lyman, K. (1990). Speeding Products to Market: Waiting Time to First Product Introduction in New Firms. Administrative Science Quarterly. 35(1), 177-207.

Scully, J.I., \& Fawcett, S.E. (1994). International procurement strategies: challenges and opportunities for small firm. Production \& Inventory Management Journal, 35(2), 39-46.

Sinha, P., Akoorie, M.E.M, Ding, Q. \& Wu. Q. (2011). What motivates manufacturing SMEs to outsource offshore in China? Comparing the perspectives of SME manufacturers and their suppliers. Strategic Outsourcing. An International Journal, 4(1), 67-88.

Swink, M.L., \& Mabert, V.A. (2000). Product development partnerships: Balancing the needs of OEMs and suppliers. Business Horizons, 43(3), 59-68.

Teece, D.J., Pisano, G., \& Shuen, A. (1997). Dynamic capabilities and strategic management. Strategic Management Journal, 18 (7), 509-533.

Treffler, D. (2008). Policy Responses to the New Offshoring: Think Globally, Invest Locally. Ottawa: Industry Canada Working Paper Series, 2008-11-25.

Upton, D.M. (1994). The management of manufacturing flexibility, California Management Review, 72- 89.

Vaccaro, I. G., Jansen, J. J., Van Den Bosch, F. A., \& Volberda, H. W. (2012). Management innovation and leadership: The moderating role of organizational size. Journal of Management Studies, 49(1), 28-51.

Veilleux, S., Haskell, N. \& Pons, F. (2012). Going global: how smaller enterprises benefit from strategic alliances, Journal of Business Strategy, 33(5), 22 - 31.

Vivek, S. D., Banwet, D. K, \& Shankar, R. (2008). Analysis of interactions among core, transaction and relationship specific investments: The case of offshoring. Journal of Operations Management, 26(2), 180-197.

Voss, C., Tsikriktsis, N., \& Frohlich, M. (2002). Case research in operations management. International journal of operations \& production management, 22(2), 195-219.

Wagner, S., \& Busse, C. (2008). Managing Innovation at Logistics Service Providers-An Introduction. In Managing Innovation-The New Competitive Edge for Logistics Service Providers, (ed.) S. Wagner, and C. Busse, 1-12. Berne: Haupt.

Yin, R. (1993). Applications of case study research, Beverly Hills, CA, Sage.

\section{Tables 1}


$8^{\text {th }}$ International Conference on Modern Research in

Management, Economics and Accounting

October 19-21, 2018 / Munich - Germany

Table 1: Criteria for Case and Interviewee Selection

\begin{tabular}{|c|c|c|}
\hline & Measures & Rationales \\
\hline \multicolumn{3}{|c|}{ Criteria for firms } \\
\hline $\begin{array}{l}\text { Offshoring } \\
\text { experience }\end{array}$ & Three years or more & $\begin{array}{l}\text { To confirm that the firms are familiar with } \\
\text { offshoring and had time to get adequate experience. }\end{array}$ \\
\hline $\begin{array}{l}\text { Type of } \\
\text { Offshoring }\end{array}$ & $\begin{array}{l}\text { Manufacturing offshoring SMEs } \\
\text { from different sectors }\end{array}$ & To cover a wide range of cases. \\
\hline Firm size & $\begin{array}{l}\text { No less than } 20 \text { employees or } \\
\text { more than } 500 \text {. All of these are } \\
\text { medium size firms. }\end{array}$ & $\begin{array}{l}\text { To indicate the activities of a systematic management } \\
\text { model in offshoring. Typical firms whose results can } \\
\text { be generalizable. }\end{array}$ \\
\hline $\begin{array}{l}\text { Rate of } \\
\text { offshoring }\end{array}$ & $\begin{array}{l}\text { Minimum } 10 \% \text { of annual revenue } \\
\text { should come from offshore } \\
\text { outsourcing activities }\end{array}$ & $\begin{array}{l}\text { To show that offshore outsourcing is an important part } \\
\text { of the firm and success and failure in offshoring will } \\
\text { have major impact on the firm's competitive } \\
\text { advantages. }\end{array}$ \\
\hline \multicolumn{3}{|c|}{ Criteria for interviewees } \\
\hline $\begin{array}{l}\text { Status of the } \\
\text { interviewees }\end{array}$ & $\begin{array}{l}\text { Mid-to higher-level manager/ } \\
\text { decision makers in offshoring } \\
\text { activities. }\end{array}$ & $\begin{array}{l}\text { To be close or involved with the offshoring so that the } \\
\text { real picture can be extracted from them. }\end{array}$ \\
\hline $\begin{array}{l}\text { Experience } \\
\text { of the } \\
\text { interviewees }\end{array}$ & $\begin{array}{l}\text { At least three years consecutive } \\
\text { experience in offshoring } \\
\text { activities at the same firm. }\end{array}$ & $\begin{array}{l}\text { To make sure that the interviewees are familiar with } \\
\text { the management process of offshoring and the } \\
\text { offshoring issues in their current firms. }\end{array}$ \\
\hline $\begin{array}{l}\text { Knowledge } \\
\text { of } \\
\text { offshoring }\end{array}$ & $\begin{array}{l}\text { Expected to have sufficient } \\
\text { offshoring knowledge }\end{array}$ & $\begin{array}{l}\text { To indicate that the interviewees can understand the } \\
\text { questions being asked and can provide appropriate } \\
\text { answers. }\end{array}$ \\
\hline
\end{tabular}


$8^{\text {th }}$ International Conference on Modern Research in

Management, Economics and Accounting

October 19-21, 2018 / Munich - Germany

Table 2: Descriptive Statistics of Selected Cases

\begin{tabular}{|l|l|l|l|l|l|l|l|}
\hline $\begin{array}{l}\text { Name } \\
\text { of } \\
\text { Firms }\end{array}$ & Sectors & $\begin{array}{l}\text { Product } \\
\text { Complex } \\
\text { ity }\end{array}$ & $\begin{array}{l}\text { Interviewee } \\
\text { status }\end{array}$ & $\begin{array}{l}\text { Foreign } \\
\text { Office }\end{array}$ & $\begin{array}{l}\text { \# of } \\
\text { supplier } \\
\text { s }\end{array}$ & $\begin{array}{c}\text { \% } \\
\text { Offshored }\end{array}$ & $\begin{array}{l}\text { Offshoring } \\
\text { since }\end{array}$ \\
\hline RG & Shoes & LT & Director SCM & Yes & $>5$ & $>50 \%$ & 2000 \\
\hline FP & Plastic & LT & VP & No & $>4$ & $>50$ & 2007 \\
\hline & & & & & & & \\
\hline GR & Equipment & LMT & VP SCM & Yes & $>10$ & $>30$ & 1999 \\
\hline SI & Utensils & LMT & VP & Yes & 12 & $>25 \%$ & 2001 \\
\hline ER & Equipment & LMT & CEO & No & $>3$ & $>20 \%$ & 2000 \\
\hline CR & Electric & LMT & VP & Yes & 10 & $>30 \%$ & 2002 \\
\hline & & & & & & & \\
\hline PW & Instruments & MT & VP (Operation) & No & $>3$ & $>35 \%$ & 2005 \\
\hline IR & Slaughter system & MT & Director SCM & No & $>10$ & $>25 \%$ & 1998 \\
\hline & & & & & & & \\
\hline MR & Equipment & MHT & Director SCM & Yes & $>4$ & $>30 \%$ & 1990 \\
\hline CN & Engineering & MHT & VP SCM & Yes & $>10$ & $>40 \%$ & 1990 \\
\hline
\end{tabular}

LT=Low-tech, LMT=Lower-mid-tech, MT=Mid-tech, MHT=Mid-to-high-tech 
$8^{\text {th }}$ International Conference on Modern Research in

Management, Economics and Accounting

October 19-21, 2018 / Munich - Germany

Table 3: Categories of Content Analysis

\begin{tabular}{|c|c|}
\hline \multicolumn{2}{|l|}{ Focus on CC } \\
\hline $\begin{array}{l}\text { Focused leadership } \\
\text { (strategic manager) }\end{array}$ & $\begin{array}{l}\text { Offshore outsourcing is supported by the senior management and they } \\
\text { concentrate on the retained activities and detect upcoming opportunities } \\
\text { and challenges. }\end{array}$ \\
\hline $\begin{array}{l}\text { Focus on higher value } \\
\text { added activities }\end{array}$ & $\begin{array}{l}\text { Offshoring focal firms send selected activities to the supplier firms and } \\
\text { reduce total numbers of activities undertaken in the offshoring firm. }\end{array}$ \\
\hline $\begin{array}{l}\text { Access to specialized } \\
\text { knowledge/technologies }\end{array}$ & $\begin{array}{l}\text { Savings from offshoring activities (as the firm does not need to invest in } \\
\text { those outsourced activities) are invested into capital goods and feedbacks } \\
\text { received from suppliers on core activities and new } \\
\text { possibilities/opportunities. }\end{array}$ \\
\hline $\begin{array}{l}\text { Enhancing core business } \\
\text { capability }\end{array}$ & $\begin{array}{l}\text { Divesting through offshoring allows the focal firm to invest more in } \\
\text { engineering and skilled manpower (engineers, technicians, and } \\
\text { logisticians). }\end{array}$ \\
\hline \multicolumn{2}{|l|}{ Innovation capabilities } \\
\hline $\begin{array}{l}\text { Product engineering } \\
\text { capabilities }\end{array}$ & $\begin{array}{l}\text { Offshoring allows exchange of engineers and technicians between } \\
\text { offshoring focal and supplier firms to work on the same product. }\end{array}$ \\
\hline Process & $\begin{array}{l}\text { Offshoring tooling to supplier firms and subsequent feedback and re- } \\
\text { adjustments of the process for production. }\end{array}$ \\
\hline New ideas and concepts & Feedback and new ideas on new product or process from suppliers. \\
\hline $\begin{array}{l}\text { Organizational learning } \\
\text { and research \& } \\
\text { development. }\end{array}$ & $\begin{array}{l}\text { Suppliers' experience and their learning from working with large } \\
\text { multinationals as well as their investment in R\&D contribute to the } \\
\text { organizational learning of offshoring focal firm. }\end{array}$ \\
\hline \multicolumn{2}{|c|}{ New product and market development } \\
\hline Collaboration on NPD & $\begin{array}{l}\text { Offshoring firms collaborate with supplier for a new product or } \\
\text { significantly modifying an existing product. }\end{array}$ \\
\hline Reduced cycle time & Offshoring to suppliers contributes faster product or process development. \\
\hline New market penetration & $\begin{array}{l}\text { Offshoring helps to raise the market share in Canada or other exporting } \\
\text { countries. }\end{array}$ \\
\hline Close to end market & $\begin{array}{l}\text { Offshoring contributes to export more to the supplier's local market or the } \\
\text { neighboring countries. }\end{array}$ \\
\hline \multicolumn{2}{|l|}{ Improving flexibility } \\
\hline Product \& process & Offshoring contributes to manufacturing flexibility. \\
\hline Volume & Offshoring helps to adjust easily with the market trends. \\
\hline Machining & $\begin{array}{l}\text { Refining the product by machine tools and the different kind of machining } \\
\text { are shared with suppliers. }\end{array}$ \\
\hline Personnel & $\begin{array}{l}\text { Personnel are formed in multitasking and inbreeding with the personnel of } \\
\text { supplier firms. }\end{array}$ \\
\hline \multicolumn{2}{|l|}{ SCA } \\
\hline Market share & $\begin{array}{l}\text { Offshore outsourcing contributes to higher market share (local and/or export } \\
\text { market in terms of volume and value). }\end{array}$ \\
\hline Specialization & $\begin{array}{l}\text { Offshoring focal firms become more specialized in higher value added } \\
\text { activities. }\end{array}$ \\
\hline Productivity & $\begin{array}{l}\text { Productivity increases following offshoring due to investment in and } \\
\text { production of higher value added activities. }\end{array}$ \\
\hline
\end{tabular}




\section{Table 4: "Three-S" Evolution Process for Dynamic Capabilities}

\begin{tabular}{|c|c|c|}
\hline Evolutionar & Explanations & Evidence from the Cases \\
\hline Sensing & $\begin{array}{l}\text { Offshoring SMEs start first with identifying and } \\
\text { anticipating the trends in the macro, meso, and } \\
\text { microenvironments surrounding their business } \\
\text { activities. Sensing capability refers to the capacity to } \\
\text { spot, interpret, and pursue opportunities in the } \\
\text { environment through generating, disseminating, and } \\
\text { responding to market intelligence (Teece, 2007). Based } \\
\text { on their perception of dynamic environment and } \\
\text { available resources, managers develop and deploy } \\
\text { different forms of dynamic capabilities. Hyper- } \\
\text { competitive business environments require firms to } \\
\text { continuously modify and revamp the firm's activities in } \\
\text { order to keep good fit with the enterprise ecosystem. } \\
\text { From this stage, the focal firms start to look for } \\
\text { suppliers with complementary resources, competences } \\
\text { and capabilities for inter-firm resource configuration. }\end{array}$ & $\begin{array}{l}\text { Local market openness and accelerated changes in the } \\
\text { export markets led manufacturing SMEs to look for } \\
\text { alternatives for improving competitiveness. The VP of the } \\
\text { Firm FP describe their case as: } \\
\text { "In 2006, the company experienced a major crisis, mainly } \\
\text { due to the appreciation of the exchange rate, which } \\
\text { melted the profits in United States, where we realized } \\
\text { about } 65 \% \text { of our turnover. We quickly adopted lean } \\
\text { manufacturing, which helped to improve our sales but } \\
\text { was insufficient to correct the situation, as the gains were } \\
\text { eroded by the appreciated US dollar." In } 2008 \text {, China } \\
\text { appeared on our radar screen and "I went to China with } \\
\text { ACIP-Québec [Canadian Association of Plastics } \\
\text { Industry] and we found suppliers with complementary } \\
\text { capabilities to our products." [Translation from French } \\
\text { text]. }\end{array}$ \\
\hline Seizing & $\begin{array}{l}\text { Sensing the macro, meso, and micro trends allows } \\
\text { managers to mobilize inter-firm resources in } \\
\text { collaboration with supplier firms to capture available } \\
\text { opportunities and sustain in the volatile marketplace. It } \\
\text { helps them to prioritize their resource allocation and } \\
\text { location of modular activities on a competitive basis. } \\
\text { Managers develop consensus among the senior } \\
\text { members about the strategic intent and aligning the } \\
\text { business model and strategy with the offshoring } \\
\text { supplier firms. }\end{array}$ & $\begin{array}{l}\text { "Our products were innovative but we could not diversify } \\
\text { our market due to the resource constraints," said the } \\
\text { market development director of the firm RG. He further } \\
\text { added: "We found some sourcing partner through an } \\
\text { 'intermediate search firm' and agreed to offshore some of } \\
\text { our activities, which gave us the scale economy and we } \\
\text { went to the European market for our high-end sports } \\
\text { garments." }\end{array}$ \\
\hline Shaping & $\begin{array}{l}\text { Following sensing the market trends and adopting the } \\
\text { strategic decisions to capture the available } \\
\text { opportunities offered in the market, offshoring firms } \\
\text { devise plausible responses to the market trends by } \\
\text { modifying existing or developing new or exploring } \\
\text { new ways of their manufacturing activities. Managers } \\
\text { develop co-evolving strategies through connecting with } \\
\text { the best performing supplier firms for generating } \\
\text { synergetic resources and reconfiguring them for } \\
\text { responding to the hyper-velocity market requirements. }\end{array}$ & $\begin{array}{l}\text { "The Canadian market is very open to foreign } \\
\text { companies, not vice versa, particularly since the Buy } \\
\text { American Act," said the VP of supply chain management } \\
\text { of the firm CN. He added, "Increased foreign } \\
\text { competition in the home market and introduction of the } \\
\text { Buy American Act have forced us to redefine our } \\
\text { activities. We have opened 'design development centers, } \\
\text { in Romania and India, where skilled architects are } \\
\text { available competitively and developed offshoring } \\
\text { collaboration with firms south of the border and assemble } \\
\text { our product there to sell in the American public sector } \\
\text { market." }\end{array}$ \\
\hline
\end{tabular}


$8^{\text {th }}$ International Conference on Modern Research in

Management, Economics and Accounting

October 19-21, 2018 / Munich - Germany

Table 5: Offshore Outsourcing and Dynamic Capabilities Development

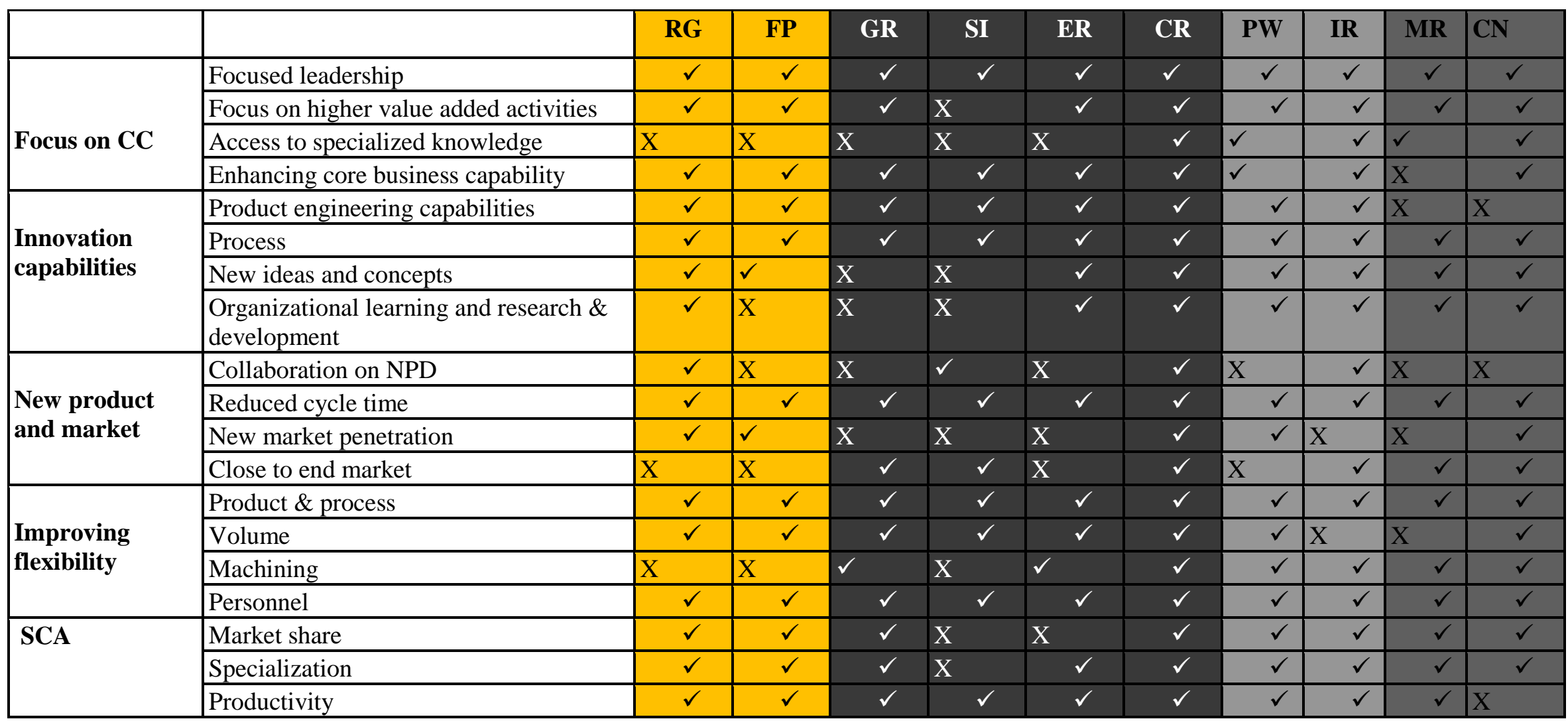

$=$ Higher or improved, $\mathrm{X}=$ No change 
$8^{\text {th }}$ International Conference on Modern Research in

Management, Economics and Accounting

October 19-21, 2018 / Munich - Germany

\section{Table 6: Level of Dynamic Capacities Development Process}

\begin{tabular}{|c|c|c|}
\hline $\begin{array}{l}\text { Dynamic } \\
\text { capabilities level }\end{array}$ & Explanations & Evidence from the cases \\
\hline Incremental & $\begin{array}{l}\text { Offshore outsourcing SMEs, who consider the market is moving slowly, } \\
\text { develop incrementally their resources and competences as well as adapt } \\
\text { their business processes to their resources and competences. This is } \\
\text { considered as first-level dynamic capability. This is the case for low- } \\
\text { tech firms that enter into efficiency seeking offshore outsourcing for } \\
\text { low-cost production location. The incremental dynamic capabilities } \\
\text { development process does not necessarily change the resource base and } \\
\text { offshoring SMEs are mostly re-active than pro-active in their offshoring } \\
\text { strategy. }\end{array}$ & $\begin{array}{l}\text { VP of the firm RG mentioned, "We had first relocated our } \\
\text { manufacturing low-cost activities to China in the '90s" (but due } \\
\text { to the rapid rise of wages and other production factors) "we have } \\
\text { relocated our Chinese facilities to Cambodia where production } \\
\text { cost is at least } 20 \% \text { less than the previous place." [Translation } \\
\text { from French text]. He further added, "the host country's } \\
\text { contribution to our value creation is low." }\end{array}$ \\
\hline Renewing & $\begin{array}{l}\text { In a comparatively dynamic environment, offshoring SMEs follow both } \\
\text { the efficiency and the growth strategy. The latter strategy requires focal } \\
\text { firms to refresh and renew their resource stocks and enlarge them by } \\
\text { collaborating with supplier firms in lieu of incrementally adapting to the } \\
\text { external environment. While incremental dynamic capabilities refer to } \\
\text { adjusting, and incrementally improving, renewing dynamic capabilities } \\
\text { are concerned with "the capability of an organization to purposefully } \\
\text { create, extend, or modify its resource base" (Helfat, et al., 2007). }\end{array}$ & $\begin{array}{l}\text { The firm SI is a manufacturer of stoves since 1996. In early years } \\
\text { of its efficiency-led outsourcing since 2002, SI renewed its } \\
\text { resources base by in-house R\&D and savings from the offshoring. } \\
\text { It introduced new models of the same product. It had then } \\
\text { offshored its activities to Brazil and eastern Europe first for low- } \\
\text { cost production location. This strategy enabled it to develop its } \\
\text { efficiency level and productivity by refreshing its resource base } \\
\text { without radically changing the dynamic capabilities. }\end{array}$ \\
\hline Regenerative & $\begin{array}{l}\text { In a hyper-turbulent business environment and for higher-technology } \\
\text { firms, offshoring allow them to regenerate dynamic capabilities in } \\
\text { collaboration with their suppliers to modify their current dynamic } \\
\text { capabilities and create new ones suitable for the new environment. They } \\
\text { involve restructuring, learning, leverage, and impact on the renewing or } \\
\text { incremental dynamic capabilities. These are the higher-level } \\
\text { capabilities. }\end{array}$ & $\begin{array}{l}\text { Since 2006, SI started to develop closer ties with its supplier firms } \\
\text { by concentrating on fewer large-scale suppliers who are } \\
\text { considered as lead firms in their respective activities. These large } \\
\text { outsourcing supplier firms invest heavily in their R\&D and gained } \\
\text { experience through working with other large and/or innovative } \\
\text { companies. The close relation with lead suppliers and a few } \\
\text { acquisitions in West Canada allowed this firm to introduce new } \\
\text { high-end products and high-end products in related industries. By } \\
\text { doing so, SI developed its capabilities by entering the low-cost } \\
\text { production base, accessing R\&D of lead suppliers, and the } \\
\text { acquisition of other firms. This new configuration of its resources } \\
\text { enhanced its higher-level dynamic capabilities, considered } \\
\text { "regenerative" capabilities, as these capabilities can further } \\
\text { improve the capability level of the firm. }\end{array}$ \\
\hline
\end{tabular}


$\underline{\text { Figure } 1}$

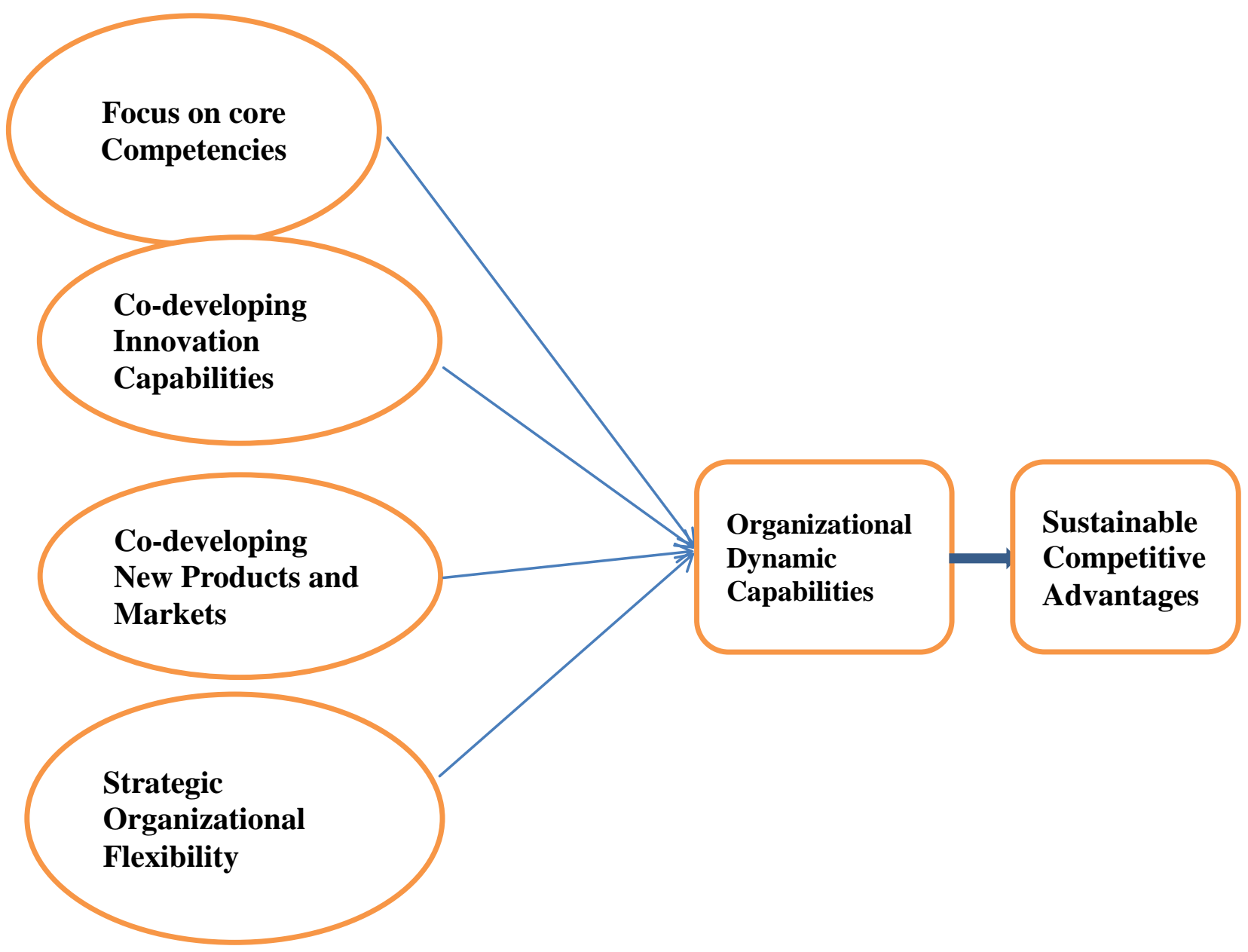

Figure 1: Dynamic capabilities and SCA 